\title{
Studies of the possible transference of flavonol antioxidants from the diet to the tissue lipids of rats
}

\author{
By A. LETAN* \\ Low Temperature Research Station, Cambridge \\ (Received I6 fuly 1966-Accepted 5 December 1966)
}

\begin{abstract}
I. The oxidative stability of lipids in the tissues (erythrocytes, liver and depot fat) from vitamin E-deficient rats was not improved by feeding these animals, for a period of 39-55 days before killing, on a vitamin E-free diet richly supplemented with the flavonoid antioxidants quercetin $\left(3,5,7,3^{\prime}, 4^{\prime}\right.$-pentahydroxyflavone $)$ and flavone $\left(3,7,8,2^{\prime}, 5^{\prime}\right.$-pentahydroxy-6tert.-butyl flavone).

2. Addition of $\alpha$-tocopherol (in the form of $\alpha$-tocopheryl acetate) to the diet relieved, as expected, the investigated symptoms of vitamin $\mathbf{E}$ deficiency and greatly improved the stability of the tissue lipids.

3. Quercetin and flavone, when added in vitro to liver homogenate or to extracted adipose tissue, strongly retarded oxidation. It was concluded that those flavonols either were not absorbed by the animals or were destroyed in the body.
\end{abstract}

It is widely believed that one, possibly major, function of vitamin $\mathrm{E}$ in animal tissues is as an in vivo antioxidant protecting the readily peroxidizable unsaturated lipids (Dam \& Granados, 1945; Dam, I957; Horwitt, 196I). In animals vitamin E deficiency causes the following pathological symptoms, apparently related to the above : encephalomalacia (Century \& Horwitt, 1959; Century, Horwitt \& Bailey, 1959; Machlin \& Gordon, I960) and exudative diathesis (Bieri \& Pollard, 1959) in chicks, tissue peroxidation (Dam, 1957; Moore, Sharman \& Ward, r959; Zalkin \& Tappel, 1960), susceptibility of erythrocytes to haemolysis (Dam, 1956; Friedmann, Weiss, Wherry $\&$ Kline, 1958), susceptibility of erythrocytes, microsomes and mitochondria to lipid peroxidation (Bunyan, Green, Edwin \& Diplock, I960; Tsen \& Collier, 1960; Tappel \& Zalkin, $1959 b, 1960$ ), susceptibility of abdominal fat to autoxidation (Lundberg, Barnes, Clausen \& Burr, 1944; Lundberg, Barnes, Clausen, Larson \& Burr, 1947; Burr, Lundberg \& Chipault, 1946).

Animals obtain their tocopherol from the diet; ingested tocopherols are readily absorbed and deposited in body lipids.

Substituting other antioxidants for vitamin $\mathrm{E}$ in diets has been tried by several workers, who studied the capacity of certain animals to absorb synthetic antioxidants and the ability of these antioxidants to perform in vivo some of the functions of vitamin $\mathrm{E}$.

Dam, Kruse, Prange \& Søndergaard (r948, I95 I) showed that NDGA (nordihydroguaiaretic acid) fed to chicks provided protection against exudative diathesis and encephalomalacia. Bunnell, Matterson, Singsen, Potter, Kozeff \& Jungherr (1955) and Singsen, Bunnell, Matterson, Kozeff \& Jungherr (1955) reported that signs of

* Present address: Department of Food and Biotechnology, Technion-Israel Institute of Technology, Haifa, lsrael. 
encephalomalacia in chicks were prevented by addition of DPPD $\left(N, N^{\prime}\right.$-diphenyl- $p$ phenylenediamine) to their diet; Ascarelli, Budowski, Bornstein $\&$ Bondi (I960) were able to detect the presence of orally ingested DPPD in the carcass (mainly in the body fat and liver) and in the egg yolk.

Other synthetic antioxidants, BHA (a mixture of 2- and 3-tert.-butyl-4-hydroxyanisole), BHT (2,6-di-tert.-butyl-4-methylphenol) and santoquin (ethoxyquin, 2,2,4-trimethyl-6-ethoxy-1,2-dihydroquinoline), have also been shown to provide protection against various signs of vitamin $\mathrm{E}$ deficiency (Bunnell et al. I955; Johnson, O'Halloran \& Hewgill, I958; Machlin, Gordon \& Meisky, 1959; Wilson, Thomas, Thompson, Launer \& Kohler, 1959). François \& Pihet (1960) noticed that the induction time of adipose tissue was increased by a diet with high levels of BHT and DPPD. Simpler phenolic antioxidants, such as quinol, were reported to have no such protective effect (Lundberg et al. I944; Lundberg et al. 1947; Burr et al. I946).

The study now presented was undertaken to establish whether orally ingested non-tocopherol antioxidants of the polyhydroxyflavone group might be absorbed from the intestine by rats and exert an antioxidant effect in the tissues, either directly or by conservation of a suboptimal supply of tocopherol. The polyhydroxyflavones were of interest in view of their wide distribution in the plant kingdom (Bate-Smith, 1954) and thus frequent presence in many foods of plant origin. They are classed as multifunctional antioxidants, their molecules combining both chain-breaking and metaldeactivating properties (Lea, 1958), and their in vitro antioxidant capacities have been shown to be of the same order as those of the tocopherols (Letan, I962).

Two polyhydroxyflavones were chosen for this purpose: quercetin $\left(3,5,7,3^{\prime}, 4^{\prime}-\right.$ pentahydroxyflavone), the commonest flavonol of the plant kingdom (Bate-Smith, I954) and a fairly efficient antioxidant (Kurth \& Chan, I95 I Letan, I966), and the flavone, 3,7,8,2',5'-pentahydroxy-6-tert.-butyl flavone, a more lipophilic synthetic flavonol.

\section{EXPERIMENTAL}

\section{Animals and diets}

Sixteen vitamin E-deficient male albino rats, 250-300 $\mathrm{g}$ in body-weight, were divided into four equal groups (C, Q, F and $\mathrm{T})$. All animals were fed ad lib. over periods of 39-55 days, on a diet prepared in a Kenwood mixer, comprising the following vitamin E-deficient ingredients: McCollum's salt mixture $5 \%$, yeast powder 10\%, sucrose $42.5 \%$, casein $22.5 \%$ and melted lard $20 \%$.

Group $\mathrm{C}$ served as control, and the lard used in its diet was free of antioxidant, whereas the lard in the diets of groups $\mathrm{Q}, \mathrm{F}$ and $\mathrm{T}$ contained quercetin, flavone and $\alpha$-tocopheryl acetate respectively, the first two at $0.1 \%(w / w)$, the third at $0.1 \mathrm{I} \%$ (w/w) (to yield $0.1 \%(\mathrm{w} / \mathrm{w})$ of $\alpha$-tocopherol on hydrolysis). The antioxidants were dissolved in a few $\mathrm{ml}$ of ethanol and dispersed in the melted lard shortly before mixing with the other ingredients.

The diets were prepared every IO-I 2 days, sealed in cans and stored at $-20^{\circ}$ until required. The stock of lard was similarly stored, to protect it against autoxidation.

The mean daily intake of food was found to be $12.5 \mathrm{~g}$ per animal. The daily anti- 
oxidant intake was therefore about $2.5 \mathrm{mg}$, and the total ranged from $97.5 \mathrm{mg}$ (minimum period, i.e. 39 days on diet) to $137.5 \mathrm{mg}$ (maximum period, i.e. 55 days on diet), or $117.5 \mathrm{mg}$ on average. This amount was equal to about $\mathrm{I} \%$ of the weight of the depot fat ( $\mathrm{x} 2 \mathrm{~g}$ on average).

\section{Procedure}

Test before killing. Blood $(0.02-0.04 \mathrm{ml})$ taken from a cut in the animal's tail $24 \mathrm{~h}$ or less before killing was tested for its resistance to haemolysis by the dialuric acid test of Friedmann et al. (1958).

Killing and dissection. After killing by decapitation, a blood sample was taken from an artery with a hypodermic syringe. The body was allowed to bleed and the liver and adipose tissue were carefully removed with scissors.

Test after killing. (a) Arterial blood was heparinized and used for determination, by the thiobarbituric acid method, of the so-called lipid peroxides in its erythrocytes resulting from oxidation under dialuric acid catalysis. The modified procedure of Tsen \& Collier (1960) was used, but a stronger $(50 \%$, w/v) aqueous solution of trichloroacetic acid was added at the final stages to the graduated centrifuge tube. (b) The liver (in the form of homogenate) was also examined by the thiobarbituric acid test after incubation at $37^{\circ}$, with and without added antioxidants. The method, which is described below, was based on the techniques developed by Tappel \& Zalkin (I959a), Zalkin \& Tappel (1960) and Zalkin, Tappel \& Jordan (I960).

The liver of a freshly killed animal was washed quickly with a few $\mathrm{ml}$ of saline (isotonic aqueous solution of $\mathrm{NaCl}$ ), weighed, cut into pieces and thoroughly homogenized with $35-40 \mathrm{ml}$ of the same saline in a Potter-Elvehjem homogenizer; $4 \mathrm{ml}$ portions of the homogenate were then pipetted into a number of stoppered tubes $(2 \times 12 \mathrm{~cm})$, to each of which were added $0^{4} 4 \mathrm{ml}$ of aqueous solution of chlortetracycline (I00 ppm) and $0.1 \mathrm{ml}$ of an ethanolic solution of one of the three antioxidants (to give concentrations of $10.5^{-10} \mu \mathrm{g}$ antioxidant/g liver), or a similar volume of redistilled ethanol (control experiments). After the headspace had been filled with oxygen, the tubes were stoppered and incubated on a shaker at $37^{\circ}$. At suitable intervals, individual tubes were removed and protein and lipid precipitated with $5 \mathrm{ml}$ of trichloroacetic acid solution $(10 \%, \mathrm{w} / \mathrm{v})$, the tube contents transferred to tapered centrifuge tubes and centrifuged at $1800 \mathrm{~g}$ for $10 \mathrm{~min}$.

Duplicate portions of $2 \mathrm{ml}$ of the supernatant fraction were pipetted into graduated test tubes and $\mathrm{r} \cdot 5 \mathrm{ml}$ of aqueous solution of 2-thiobarbituric acid $(0 \cdot 75 \%$, w/v) added to each. The pink colour was developed by heating for $10 \mathrm{~min}$ in a boiling-water bath. The solutions were then cooled, made up to $4 \mathrm{ml}$ with distilled water and clarified by brief centrifugation. Their extinctions were measured at $530 \mathrm{~nm}$, after dilution where necessary.

In each incubation experiment a zero-time value was obtained by adding the trichloroacetic acid solution immediately after pipetting the homogenate. The ratios $E: W$, where $E=$ extinction of the measured solution at $530 \mathrm{~nm}$ and $W=$ weight of liver (g) in the solution, were plotted against time of incubation of the homogenate at $37^{\circ}$. 
(c) The depot fat was extracted from the adipose tissue and its resistance to autoxidation and its fatty acid composition were determined as follows.

The adipose tissues of all animals of each group were collected together in flasks; these were stoppered loosely with cotton-wool and stored in a carbon dioxide cabinet a $-80^{\circ}$ until required. To extract the fat from each of the four combined tissue samples $10 \mathrm{~g}$ of tissue were blended in a Waring Blendor with peroxide- and alkali-free ethyl ether. After three extractions with a total of $80-100 \mathrm{ml}$ of the solvent, the combined extracts were filtered through Whatman no. I paper, dried over anhydrous $\mathrm{Na}_{2} \mathrm{SO}_{4}$ ( $\mathrm{g} / \mathrm{r} \circ \mathrm{ml}$ extract) and filtered again. The ether was then driven off in a rotary vacuum evaporator at room temperature.

The four samples of fat were melted, pipetted out (in $0.2 \mathrm{ml}$ portions) into small $\left(\mathrm{I} \cdot 2 \mathrm{~cm}\right.$ diameter) cups and stored at $60^{\circ}$ in a thermostatic oven. At suitable intervals, individual cups were removed and the peroxide value of each sample was determined iodometrically by the method of Lea (1952), slightly modified: the reaction time between hydroperoxides and iodide ions was reduced to $3 \mathrm{~min}$ and de-aeration was dispensed with. According to the author's experience, the error involved was comparatively small, presumably owing to offsetting the slightly incomplete reaction by the oxygen error.

In an additional experiment $0.1-0.2 \mathrm{ml}$ of ethanolic solutions of the same threc antioxidants were added in vitro to $2.5 \mathrm{~g}$ samples of fat from the control group (C) and tested for the effect on its autoxidative stability. A fourth sample of the same fat served as a control. The strength of the antioxidant solutions added was such that the final concentration of antioxidant in the fat was $0.2 \mu$ mole/g. After evaporation of the solvent, the samples were pipetted out, stored and tested for peroxide value as described above.

The fatty acid composition of the depot fats of groups $\mathrm{C}$ and $\mathrm{T}$ was determined by gas chromatography. Small samples were converted into methyl esters by heating for $3 \mathrm{~h}$ at $100^{\circ}$ in sealed air-free ampoules with a tenfold volume of $4 \mathrm{~N}$ anhydrous methanolic hydrochloride. The ampoule was then opened and excess methanol removed under reduced pressure and the residue extracted twice with light petroleum. The solution was washed several times with water and dried over anhydrous sodium sulphate. The solvent was then driven off; the methyl ester residues were purified by distillation at about $200^{\circ}$ under reduced pressure (cold-finger technique), redissolved in 2,2,4-trimethylpentane and injected with the aid of capillaries into a PYE Argon Gas Chromatograph (equipped with an argon ionization detector containing $20 \mathrm{mc}{ }^{90} \mathrm{Sr}$ ). Analyses were carried out in duplicate on two types of liquid phase, polar and non-polar. The columns used were glass, $4 \mathrm{ft}$ long and $4 \mathrm{~mm}$ in diameter, filled with either $15 \%(\mathrm{w} / \mathrm{w})$ polyethylene glycol adipate or $15 \%(\mathrm{w} / \mathrm{w})$ Apiezon $\mathrm{L}$, both on 80-100 mesh Celite. The apparatus was operated at $185^{\circ}$ with the first type of packing and at $200^{\circ}$ with the second. Detector voltage was I000 V; the carrier gas was passed at a rate of $40 \mathrm{ml} / \mathrm{min}$. 
Vol. 2I
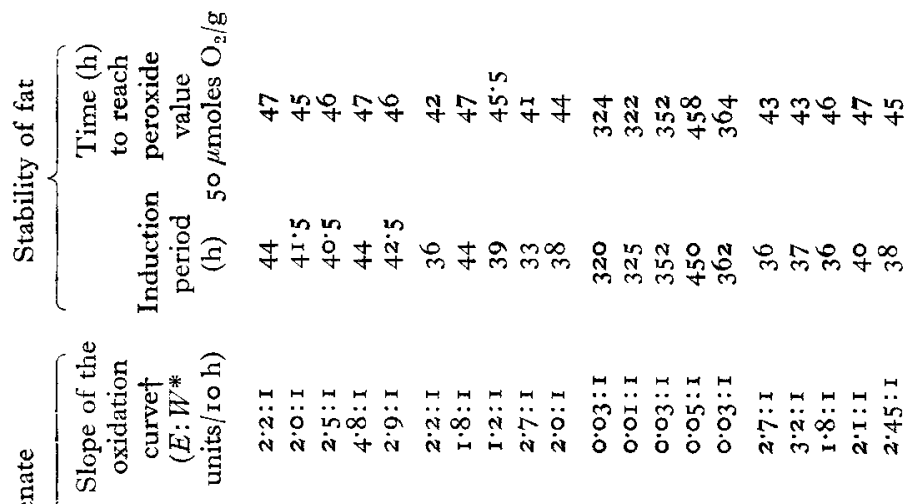

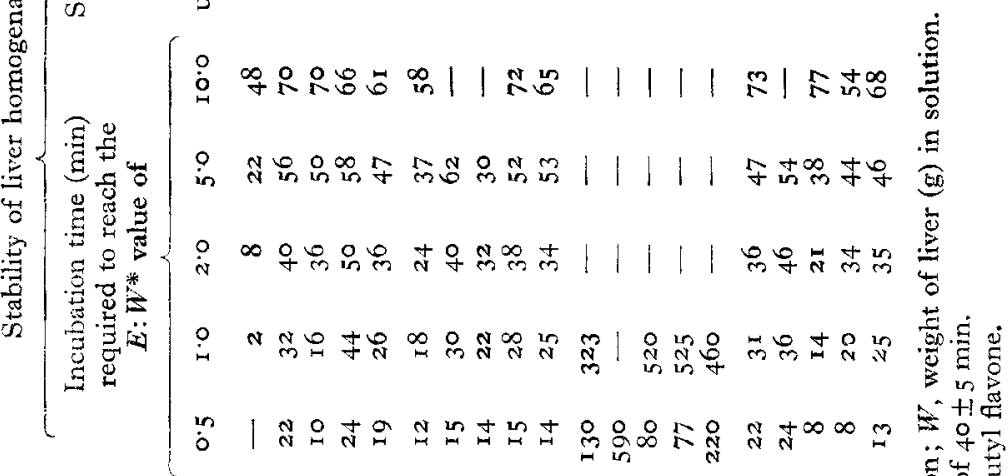

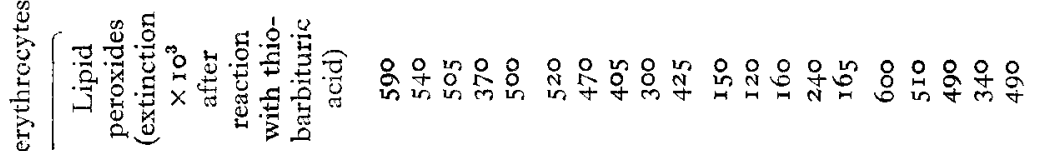

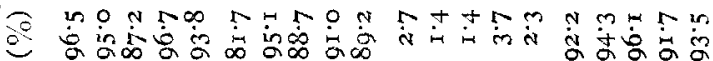
政
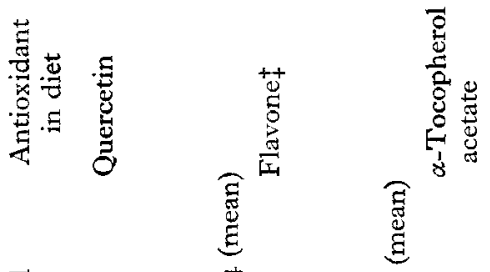

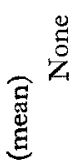<smiles>[CH][CH]</smiles>

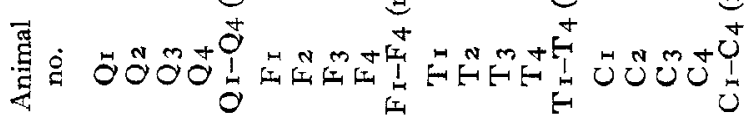




\section{RESULTS AND DISCUSSION}

Table I shows the condition of erythrocytes for each of the four groups and the oxidative stabilities of the liver homogenates and depot fats (see also Figs. I and 3 ).

There were considerable differences between control (C), quercetin (Q) and flavone (F) groups on the one hand, and the tocopherol $(\mathrm{T})$ group on the other.

Table 2. Relative activities of antioxidants added in vitro to liver homogenate of rats fed on different diets

\begin{tabular}{|c|c|c|c|c|c|c|c|c|}
\hline \multirow{3}{*}{$\begin{array}{c}\text { Animal } \\
\text { no. }\end{array}$} & & & \multicolumn{6}{|c|}{ Stability of liver homogenate } \\
\hline & \multicolumn{2}{|c|}{ Admixture to liver homogenates } & \multicolumn{5}{|c|}{$\begin{array}{l}\text { Incubation time (min) required to reach } \\
\text { the } E: W^{*} \text { value of }\end{array}$} & \multirow{2}{*}{$\begin{array}{c}\text { Slope of } \\
\text { oxidation } \\
\text { curve } \\
\left(E: W^{*}\right. \\
\text { units/ro h) }\end{array}$} \\
\hline & Antioxidant & $(\mu \mathrm{g} / \mathrm{g}$ liver $)$ & 0.5 & $\mathbf{I} \cdot 0$ & $2 \cdot 0$ & $5^{\circ} 0$ & $10 \cdot 0$ & \\
\hline$Q_{I}$ & $\begin{array}{l}\text { None } \\
\text { Quercetin }\end{array}$ & $\overline{105}$ & $\overline{28}$ & $\begin{array}{l}2 \\
96\end{array}$ & $\begin{array}{r}8 \\
-\end{array}$ & $\stackrel{22}{\longrightarrow}$ & $\underline{48}$ & $\begin{array}{l}2 \cdot 2: 1 \\
0.06: 1\end{array}$ \\
\hline$Q_{2}$ & $\begin{array}{l}\text { None } \\
\text { Quercetin }\end{array}$ & $\overline{10.5}$ & $\begin{array}{l}22 \\
22\end{array}$ & $\begin{array}{l}32 \\
33\end{array}$ & $\begin{array}{l}40 \\
40\end{array}$ & $\begin{array}{l}56 \\
66\end{array}$ & $\begin{array}{l}70 \\
96\end{array}$ & $\begin{array}{l}\text { 2.0: } 1 \\
1 \cdot 2: 1\end{array}$ \\
\hline$Q_{3}$ & $\begin{array}{l}\text { None } \\
\text { Flavonef }\end{array}$ & $\overline{12 \cdot 5}$ & $\begin{array}{l}10 \\
10\end{array}$ & $\begin{array}{l}16 \\
26\end{array}$ & $\begin{array}{l}36 \\
38\end{array}$ & $\begin{array}{l}50 \\
58\end{array}$ & $\begin{array}{r}70 \\
104\end{array}$ & $\begin{array}{l}2 \cdot 5: 1 \\
1 \cdot 5: 1\end{array}$ \\
\hline$Q_{4}$ & $\begin{array}{l}\text { None } \\
\alpha \text {-Tocopherol }\end{array}$ & $\rightarrow$ & $\begin{array}{l}24 \\
63\end{array}$ & $\begin{array}{r}44 \\
\times 60\end{array}$ & 50 & $5^{8}$ & 66 & $\begin{array}{l}4 \cdot 8: 1 \\
0.07: 1\end{array}$ \\
\hline$F_{I}$ & $\begin{array}{l}\text { None } \\
\text { Quercetin }\end{array}$ & 105 & $\begin{array}{r}12 \\
160\end{array}$ & $\begin{array}{r}18 \\
385\end{array}$ & 24 & 37 & $5^{8}$ & $\begin{array}{l}2 \cdot 2: 1 \\
0.05: 1\end{array}$ \\
\hline $\mathbf{F}_{2}$ & $\begin{array}{l}\text { None } \\
\text { Quercetin }\end{array}$ & $\overline{35}$ & $\begin{array}{l}15 \\
62\end{array}$ & $\begin{array}{l}30 \\
90\end{array}$ & $\begin{array}{r}40 \\
\times 30\end{array}$ & 62 & - & $\begin{array}{l}1 \cdot 8: 1 \\
0 \cdot 14: 1\end{array}$ \\
\hline $\mathrm{F}_{3}$ & $\begin{array}{l}\text { None } \\
\text { Flavonef }\end{array}$ & $\longrightarrow$ & $\begin{array}{l}14 \\
21\end{array}$ & $\begin{array}{l}22 \\
6 I\end{array}$ & $\begin{array}{r}32 \\
362\end{array}$ & 60 & - & $\begin{array}{l}\text { I.2: I } \\
0.16: 1\end{array}$ \\
\hline $\mathbf{F}_{4}$ & $\begin{array}{l}\text { None } \\
\alpha \text {-Tocopherol }\end{array}$ & 50 & $\begin{array}{l}15 \\
52\end{array}$ & $\begin{array}{l}28 \\
67\end{array}$ & $\begin{array}{r}38 \\
250\end{array}$ & $\frac{52}{-}$ & $\underline{72}$ & $\begin{array}{l}2 \cdot 7: 1 \\
0.06: 1\end{array}$ \\
\hline$T_{\mathbf{I}}$ & $\begin{array}{l}\text { None } \\
\text { Quercetin }\end{array}$ & - & $\begin{array}{l}130 \\
226\end{array}$ & $\begin{array}{l}323 \\
590\end{array}$ & - & - & - & $\begin{array}{l}0.03: 1 \\
0.02: I\end{array}$ \\
\hline $\mathrm{T}_{2}$ & $\begin{array}{l}\text { None } \\
\text { Flavonef }\end{array}$ & $\overline{125}$ & $\begin{array}{l}590 \\
800\end{array}$ & - & - & - & - & $\begin{array}{l}0.01: 1 \\
0.01: 1\end{array}$ \\
\hline $\mathrm{CI}_{\mathrm{I}}$ & $\begin{array}{l}\text { None } \\
\text { Quercetin }\end{array}$ & - & $\begin{array}{l}22 \\
70\end{array}$ & $\begin{array}{r}31 \\
200\end{array}$ & $\frac{36}{-}$ & 47 & $\underline{73}$ & $\begin{array}{l}2 \cdot 7: 1 \\
0.04: 1\end{array}$ \\
\hline $\mathrm{Cl}_{2}$ & $\begin{array}{l}\text { None } \\
\text { Flavonef }\end{array}$ & $\overline{125}$ & $\begin{array}{r}24 \\
800\end{array}$ & $\underline{36}$ & 46 & $\underline{54}$ & - & $\begin{array}{l}3 \cdot 2: 1 \\
0.01: 1\end{array}$ \\
\hline $\mathrm{C}_{3}$ & $\begin{array}{l}\text { None } \\
\alpha \text {-Tocopherol }\end{array}$ & - & $\begin{array}{r}8 \\
24\end{array}$ & $\begin{array}{l}\mathrm{I} 4 \\
54\end{array}$ & $\begin{array}{l}21 \\
70\end{array}$ & $3^{8}$ & $\underline{77}$ & $\begin{array}{l}1 \cdot 8: 1 \\
0.12: 1\end{array}$ \\
\hline $\mathrm{C}_{4}$ & $\begin{array}{l}\text { None } \\
\text { Quercetin }\end{array}$ & $\overline{35}$ & $\begin{array}{r}8 \\
30\end{array}$ & $\begin{array}{l}20 \\
66\end{array}$ & $\begin{array}{r}34 \\
106\end{array}$ & $\underline{44}$ & $\underline{54}$ & $\begin{array}{l}2 \cdot I: I \\
0 \cdot 16: I\end{array}$ \\
\hline
\end{tabular}

For groups $\mathrm{C}, \mathrm{Q}$ and $\mathrm{F}$ the induced haemolysis, the thiobarbituric acid extinction (lipid peroxides in the erythrocytes), the slope of the oxidation curve of the liver homogenate, and the induction period of the autoxidized fat averaged respectively $92 \%, 0.470,2.5$ and $39 \mathrm{~h}$, as against $2 \%, 0.160,0.03$ and $320 \mathrm{~h}$ for group T. It must 
Table 3. Relative in vitro antioxidant activities of quercetin, flavone* and $\alpha$-tocopherol in extracted depot fat of rats of the control $(C)$ group (concentration of the antioxidants, 0.2 umole/g fat; temperature of autoxidation, $60^{\circ}$ )

\begin{tabular}{|c|c|c|c|c|c|}
\hline \multirow[b]{2}{*}{ Antioxidant } & \multirow{2}{*}{$\begin{array}{l}\text { Induction } \\
\text { period } \\
\text { (h) }\end{array}$} & \multicolumn{2}{|c|}{$\begin{array}{l}\text { Time }(h) \text { to reach } \\
\text { peroxide value of }\end{array}$} & \multicolumn{2}{|c|}{$\begin{array}{l}\text { Protection factors } \\
\text { at peroxide value of }\end{array}$} \\
\hline & & 20 & 50 & 20 & 50 \\
\hline None & 34 & 35 & 46 & 0.0 & 0.0 \\
\hline Quercetin & 301 & 284 & 310 & $7 \cdot 1$ & $5 \cdot 7$ \\
\hline Flavone* & 245 & 220 & 254 & $5 \cdot 3$ & 4.5 \\
\hline$\alpha$-Tocopherol & 504 & 480 & - & I 2.7 & - \\
\hline
\end{tabular}

* $3,7,8,2^{\prime}, 5^{\prime}$-pentahydroxy-6-tert.-butyl flavone.

+ Defined as $\left(t_{a}-t_{c}\right) / t_{c}$, where $t_{a}=$ time with antioxidant, and $t_{c}=$ time without antioxidant, to reach an arbitrarily chosen peroxide value.

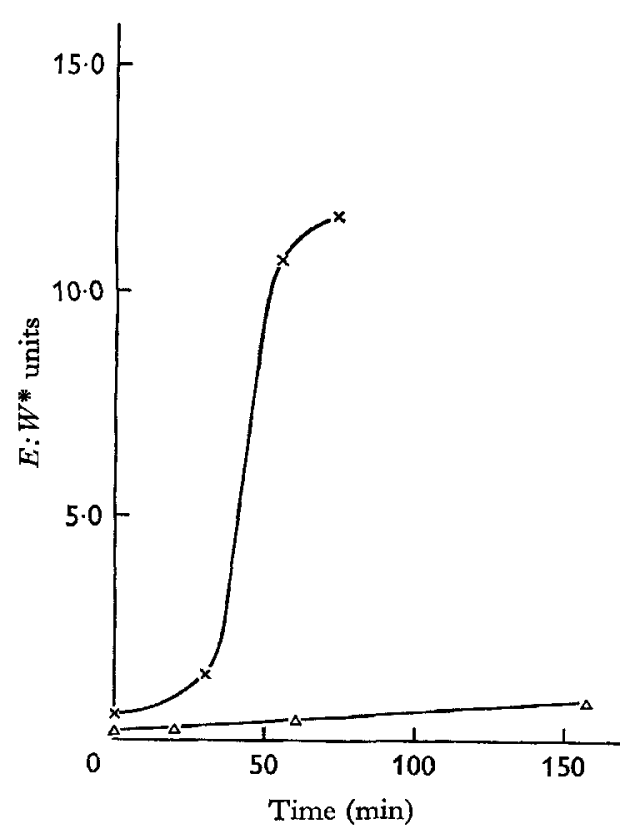

Fig. I

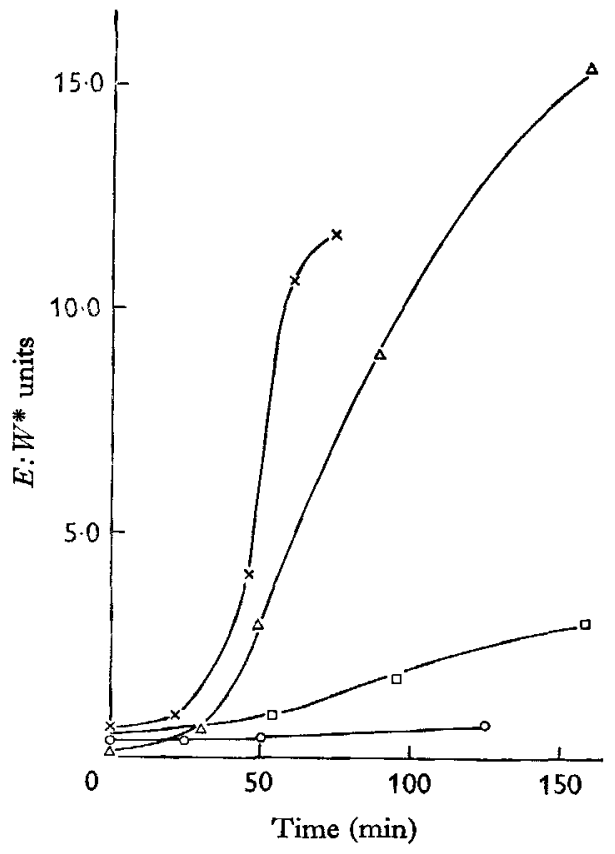

Fig. 2

Fig. I. Autoxidation at $37^{\circ}$ of liver homogenates of vitamin E-deficient rats fed on diets containing $\alpha$-tocopheryl acetate $(\triangle-\triangle)$ or no antioxidant $(x-x)$.

Fig. 2. Antioxidant activity at $37^{\circ}$ of quercetin added in vitro to a liver homogenate of a vitamin E-deficient rat at a concentration $(\mu \mathrm{g} / \mathrm{g}$ liver) of $10.5(\Delta-\Delta), 35(\square-\square)$ or 105 $(\mathrm{O}-\mathrm{O}) . \times-x$, no quercetin added.

* $E$, extinction at $53^{\circ} \mathrm{nm}$ of solution; $W$, weight of liver (g) in solution.

be concluded that the flavonoid antioxidants, fed at quite high levels, failed to exert any protective effect on the body lipids of vitamin E-deficient rats. As the same antioxidants, when added directly in vitro to liver homogenate (Table 2 and Fig. 2) and to extracted adipose tissue fat (Table 3 and Fig. 4), did provide powerful protection against oxidation, their failure when supplied in the diet must be due to non-absorption or to destruction in the body. 
Zero peroxide values were found for the depot fats of freshly killed animals of all four groups $(C, Q, F$ and $T)$ in spite of the fact that the first three were vitamin $E$ deficient. A similar observation was made by Bieri \& Anderson (I960) who found no peroxides in the fat of vitamin E-deficient chicks, contrary to the findings of Zalkin

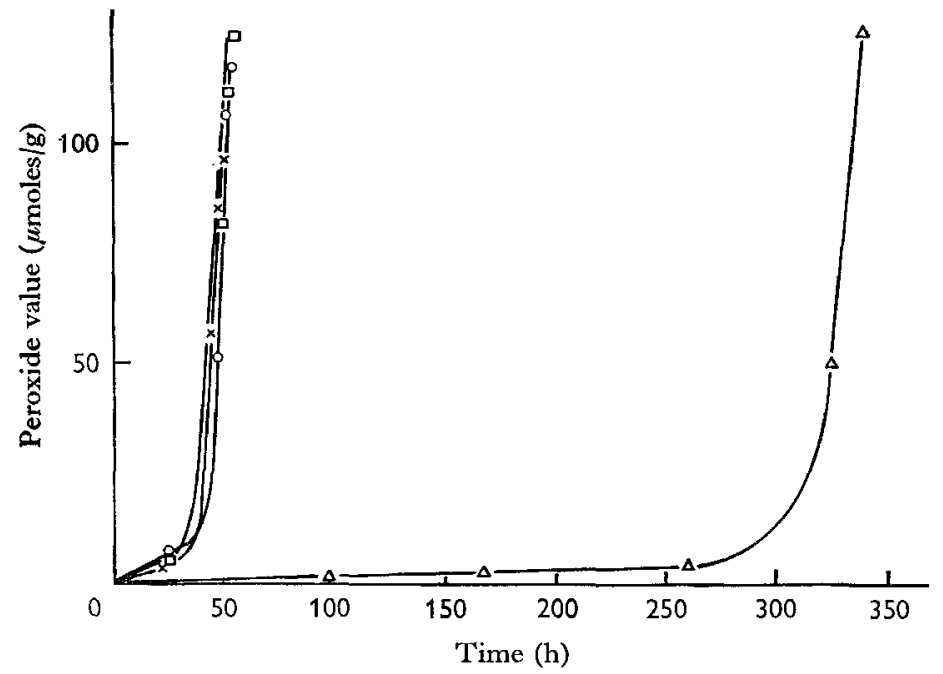

Fig. 3. Susceptibility to autoxidation at $60^{\circ}$ of the depot fat of rats fed on a diet containing quercetin $(\mathrm{O}-\mathrm{O})$, flavone $(\square-\square)$ or $\alpha$-tocopheryl acetate $(\triangle-\triangle), \times-\times$, no antioxidant added.

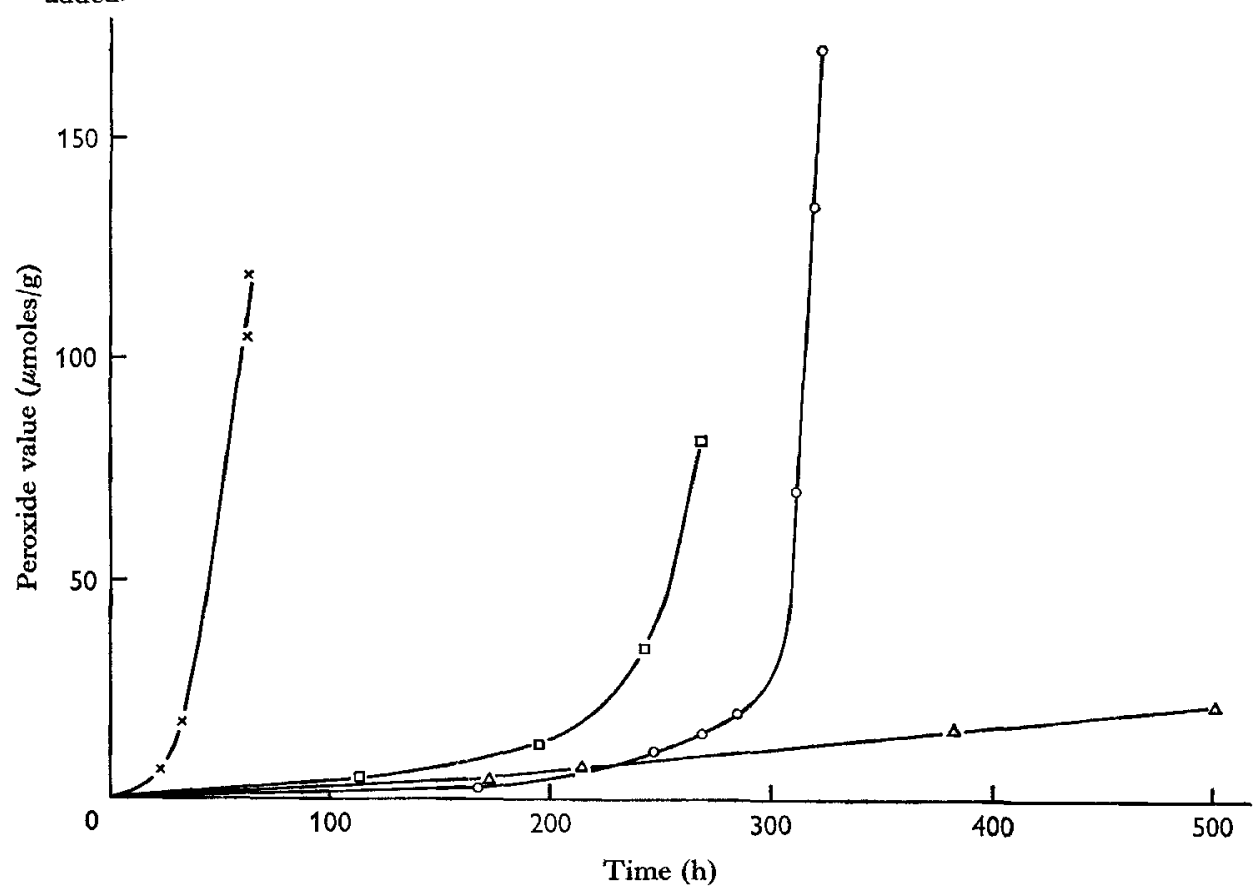

Fig. 4. Relative antioxidant activities of quercetin $(O-0)$, flavone $(\square-\square)$ and $\alpha$-tocopherpol $(\triangle-\triangle)$ in depot fat of vitamin E-deficient rats autoxidizing at $60^{\circ}$. Antioxidants were added in vitro at $0.2 \mu$ mole $/ g$ fat. $\times-x$, no antioxidant added. 
\& Tappel ( 1960 ) and others, who claimed in vivo lipid peroxidation in vitamin Edeficient animals.

No significant difference in fatty acid composition was observed between the depot fats of groups $\mathrm{C}$ and $\mathrm{T}$. Mean results were: $14: 0-1.2 \%, \mathrm{I}_{5}: 0-0.1 \%, 16: 0$ $-24.1 \%$, I6: 1 $-5.2 \%$, I $7: 0-0.7 \%$, 18:0 $-6.0 \%$, I $8: 1-55.5 \%$, I $8: 2-6.5 \%$, 20: $\mathrm{x}-0.5 \%$.

The author wishes to thank Dr C. H. Lea, Head of the Department of Fats and Lipids at the Low Temperature Research Station, Cambridge, for supervising the study. Grateful acknowledgement is due to $\mathrm{Mr}$ A. Hobson-Frohock for help in the experiments calling for team work by two, and to Mr Eliezer Goldberg for editorial assistance. This work formed a part of a thesis accepted for the degree of PhD by the University of Cambridge.

\section{REFERENCES}

Ascarelli, I., Budowski, P., Bornstein, S. \& Bondi, A. (1960). F. Sci. Fd Agric. II, $5 \circ 9$.

Bate-Smith, E. C. (1954). Adv. Fd Res. 5, 261.

Bieri, J. G. \& Anderson, A. A. (1960). Archs Biochem. Biophys. 9o, 105.

Bieri, J. G. \& Pollard, C. J. (1959). F. Nutr. 69, 301.

Bunnell, R. H., Matterson, R. D., Singsen, E. P., Potter, L. M., Kozeff, A. \& Jungherr, E. L. (1955). Poult. Sci. 34, 1068.

Bunyan, J., Green, J., Edwin, E. E. \& Diplock, A. T. (1960). Biochem. F. 77, 47.

Burr, G. O., Lundberg, W. O. \& Chipault, J. R. (1946). Oil Soap 23, 382.

Century, B. \& Horwitt, M. K. (1959). Proc. Soc. exp. Biol. Med. 102, 375.

Century, B., Horwitt, M. K. \& Bailey, P. (1959). Archs gen. Psychiat. 1, 420.

Dam, H. (1956). Acta physiol. scand. 35, 2 I5.

Dam, H. (1957). Pharmac. Rev. 9, r.

Dam, H. \& Granados, H. (1945). Acta physiol. scand. 10, 162.

Dam, H., Kruse, I., Prange, I. \& Søndergaard, E. (1948). Biochim. biophys. Acta 2, 5or.

Dam, H., Kruse, I., Prange, I. \& Søndergaard, E. (r95 I). Acta physiol. scand. 22, 299.

François, A. C. \& Pihet, A. (1960). Ann. Zootech. 9, I95.

Friedmann, L., Weiss, W., Wherry, F. \& Kline, O. L. (I958). F. Nutr. 65, I 43.

Horwitt, M. K. (196I). Borden's Rev. Nutr. Res. 22, I.

Johnson, A. R., O'Halloran, M. W. \& Hewgill, F. R. (1958). F. Am. Oil Chem. Soc. 35, 496.

Kurth, E. F. \& Chan, F. L. (195 I). F. Am. Oil Chem. Soc. 28, 433.

Lea, C. H. (1952). F. Sci. Fd Agric. 3, 586.

Lea, C. H. (1958). J. Sci. Fd Agric. 9, 621.

Letan, A. (1962). On the inhibition of the oxidation of unsaturated lipids by naturally-occurring phenolic substances. $\mathrm{PhD}$ Thesis, University of Cambridge.

Letan, A. (1966). F. Fd Sci. 31, 5 18.

Lundberg, W. O., Barnes, R. H., Clausen, M. \& Burr, G. O. (1944). F. biol. Chem. 153, 265.

Lundberg, W. O., Barnes, R. H., Clausen, M., Larson, N. \& Burr, G. O. (1947). F. biol. Chem. r68, 379.

Machlin, L. J. \& Gordon, R. S. (1960). Proc. Soc. exp. Biol. Med. ro3, 659.

Machlin, L. J., Gordon, R. S. \& Meisky, I. H. (1959). F. Nutr. 67, 333.

Moore, T., Sharman, I. M. \& Ward, R. J. (1959). Br. F. Nutr. 13, 1oo.

Singsen, E. P., Bunnell, R. H., Matterson, L. D., Kozeff, A. \& Jungherr, E. L. (1955). Poult. Sci. 34, 262.

Tappel, A. L. \& Zalkin, H. (1959a). Archs Biochem. Biophys. 80, 326.

Tappel, A. L. \& Zalkin, H. (r959b). Archs Biochem. Biophys. 80, 333 .

Tappel, A. L. \& Zalkin, H. ( 960 ). Nature, Lond. I85, 35.

Tsen, C. C. \& Collier, H. B. (1960). Can. F. Biochem. Physiol. 38, 957.

Wilson, R. H., Thomas, J. O., Thompson, C. R., Launer, H. F. \& Kohler, G. O. (1959). F. Agric. Fd Ch?m. 7, 206.

Zalkin, H. \& Tappel, A. L. (1960). Archs Biochem. Biophys. 88, i 3.

Zalkin, H., Tappel, A. L. \& Jordan, J. P. (1960). Archs Biochem. Biophys. 9r, 117. 